\title{
Analysis of Market Opportunities for Use of Navigation Systems in Transport
}

\author{
Gosteva Olga Valerievna \\ dept. of Management \\ Reshetnev Siberian State University of Science and \\ Technology \\ Krasnoyarsk, Russia
}

\author{
Kukartsev Vladislav Viktorovich \\ dept. of Informatics \\ Siberian Federal University, \\ dept. of Information Economic Systems \\ Reshetnev Siberian State University of Science and \\ Technology \\ Krasnoyarsk, Russia
}

\author{
Fedorova Natalya Vladimirovna \\ dept. of Management
}

Reshetnev Siberian State University of Science and Technology

Krasnoyarsk, Russia

\author{
Lobkov Konstantin Yurevich \\ dept. of Management \\ Reshetnev Siberian State University of Science and \\ Technology \\ dept. of Department of Social and Economic Planning \\ Siberian Federal University, \\ Krasnoyarsk, Russia
}

\author{
Danilchenko Yurij Vitalevich \\ Dept. of Management \\ Reshetnev Siberian State University of Science and Technology \\ Krasnoyarsk, Russia
}

\begin{abstract}
The article discusses the effectiveness and different areas of using innovative navigation systems for transport, different markets and participation in international transport projects. The problems of ensuring information security in the operation of navigation systems in different markets and innovative activities in integrated industrial structures are considered by the example of clusters involving enterprises of the defense industry complex. It is emphasized that the analysis of market opportunities for the use of innovative navigation systems on the transport of defense enterprises allows solving several tasks at once: improving transport systems, developing dual-use technologies, presenting Russian innovation on the international market and so on. Particular attention is paid to the analysis of the possibility of using innovative navigation systems in foreign markets, as well as in the creation of transnational transport routes. The most promising markets can be considered the market of China and Kazakhstan.
\end{abstract}

Keywords - navigation systems in transport, markets, international transport networks.

\section{INTRODUCTION}

Volume and capacity of the innovative navigation systems market are important for transport.

Navigation is an integral part of human life. Navigation equipment is used wherever it is necessary to get the coordinates of the object quickly and accurately. It is mainly used by military agencies, special services, interior Ministry, emergencies Ministry, cadastral and emergency services, enterprises are engaged in the development of quarries, construction companies. In addition, such equipment is necessary for navigation and monitoring on railway, sea, public transport, in aviation, in topography, in security systems.

Different equipment is used in all used areas since navigation tasks vary greatly in complexity. It may be a simple orientation on the ground or operational management of the logistics market.

Modern navigation systems combine the capabilities of radio, digital and space technologies, which can significantly improve the efficiency and reliability of management of any vehicles, including unmanned.

Initially, navigation systems were developed for defense needs. But in modern conditions, taking into account the tasks set by the government (the commercialization of defense industries), it becomes necessary to actively apply the transfer of innovations from the defense sphere to consumer markets. The defense-industrial complex is a set of enterprises of the full cycle of production of defense products and the scientific and technical base of Russia. The innovative processes are forming through such elements as the defense industry, as research and development, research institutes, research and production associations and design bureaus, innovation processes which are the engine of economic development. 


\section{RUSSIAN LOGISTICS MARKET}

Navigation systems have high importance for the B2B market, particularly for the maintenance of logistics systems. The analysis of Russian Federation transportation total amounts in 2017 was held to assess the demand for navigation equipment at the market. Results of this analysis are presented in Table 1.

TABLE I. TOTAL TRAFFIC VOLUMES OF THE RUSSIAN FEDERATION FOR 2017

\begin{tabular}{|l|c|c|}
\hline \multicolumn{1}{|c|}{ Transport mode } & $\begin{array}{c}\text { Cost, } \\
\text { Million } \\
\text { USD }\end{array}$ & $\begin{array}{c}\text { Volume, } \\
\text { tons }\end{array}$ \\
\hline marine craft & 20311 & 34002045 \\
\hline pipeline industry & 10695 & 5861783 \\
\hline railway & 4021 & 11155458 \\
\hline airborne & 1343 & 1702 \\
\hline $\begin{array}{l}\text { composition of vehicles } \\
\text { (semi-trailer and (or) trailer } \\
\text { tractor) }\end{array}$ & 951 & 477844 \\
\hline road-transport & 439 & 214569 \\
\hline power line & 92 & 0 \\
\hline others & 0 & 9 \\
\hline
\end{tabular}

The largest volume of traffic is observed in the use of sea and rail transport. Pipeline transport volumes are lower in volume but higher in value terms. Since the vast territory of Russia is poorly equipped with the infrastructure necessary for transport, integrated navigation systems will ensure the safety and stability of traffic $[1,2]$.

The modern market of logistics services in Russia is still underdeveloped. The structure of the transport market and logistics services in Russia and in the world is presented in Figure 1.
One of the basic segments of this market development is complex and managerial logistics, which account for more than $43 \%$ of the total transportation cost, which is more than 37 billion dollars in the export of the Russian Federation.

The main factors determining the demand for complex transport and logistics services are the dynamics of the economy, globalization of cargo flows, the complexity of delivery schemes, the need to optimize the costs associated with the transportation and storage of goods.

\section{MARKET OF CHINA}

The Chinese market is very interesting too. Today China accounts for $16.5 \%$ of the world economy, compared to $16.3 \%$ for the US. The value of state financial production in 2016 in China was 17.6 trillion and 17.4 trillion dollars in America (IMF reporting). The analysis of GDP growth in China is shown in Figure 2. The steady growth of all indicators shows the attractiveness of the Chinese market $[3,4]$.

China opens up various opportunities for cooperation, holds many exhibitions, both in the capital and in the provinces. For example, the Asian economic forum is being held in the village of Boao in Hainan province, where more than 70 conferences on the development of trade and investment relations are held. Heilongjiang province shares about three thousand kilometers of the common border with Russia and it is considered to be the main participant of regional cooperation between China and Russia. As the statistics show, the volume of foreign trade of the province reached 1.41 billion dollars. The volume of trade with Russia reached \$ 840 million with a 37 percent increase.

Since 2013 the program "economic belt of the silk road" is being implemented as a new form of deepening cooperation between China, Central Asian States and Russia. This is an international project of great economic interest not only for China but for all countries along the Great silk road: Kazakhstan, Russia, Japan and other countries of South-East Asia. The project "Maritime silk road of the XXI century" was proposed with the project "Economic belt silk road" that formed a new long-term strategy of China - "One belt and one

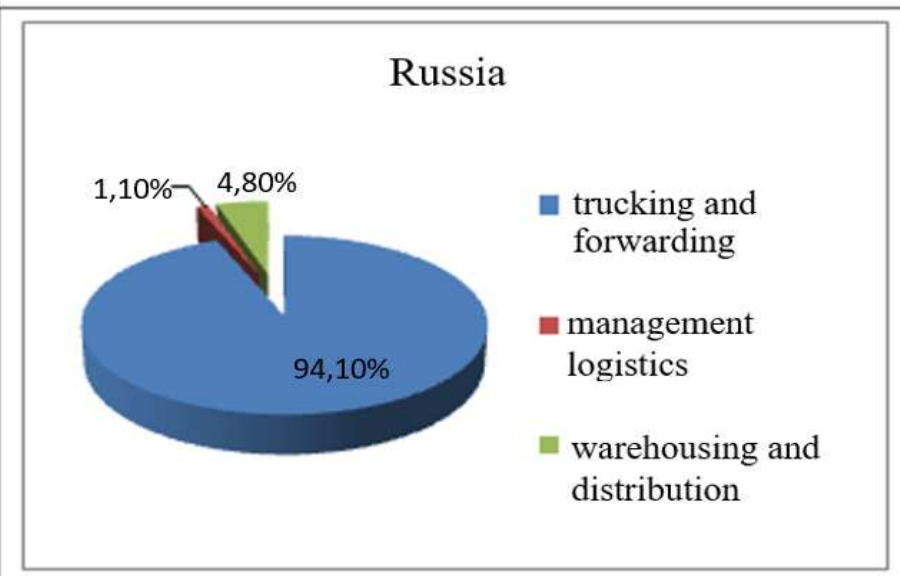

Fig. 1. Market structure of transport and logistics services in Russia and in the world

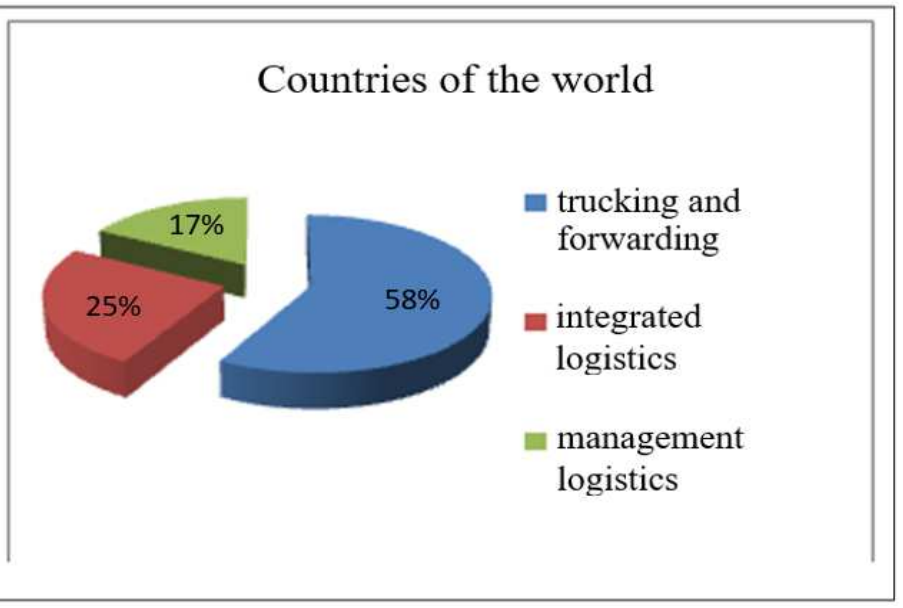

road" (Figure 3). In modern conditions, the Silk Road countries attract China with the possibility of organizing high- 
speed transit shipments of goods to Europe, as the main solvent and capacious markets in Eurasia for the sale of Chinese goods, as well as the presence of a variety of natural resources (oil, gas, metals, grain, etc.).
Eurasian continent (Europe, the Middle East and South Asia). At the same time, China is rapidly expanding its domestic railway network and has already become a world leader in the construction of high-speed lines, relying on advanced

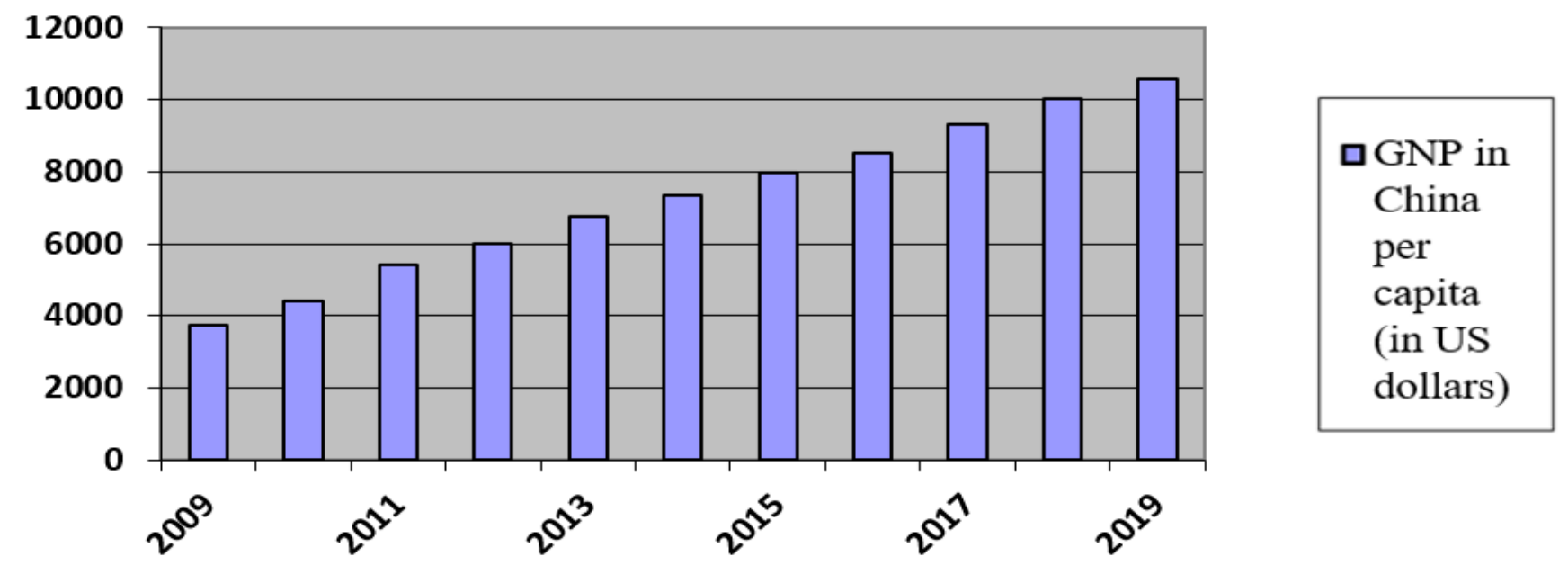

Fig. 2. Analysis of GDP growth in China per capita in current prices in the

technology and know-how in this industry. China has put period from 2009 to 2019 (in us dollars) forward ambitious plans for the construction of four highspeed international railways, two of which will be held in the

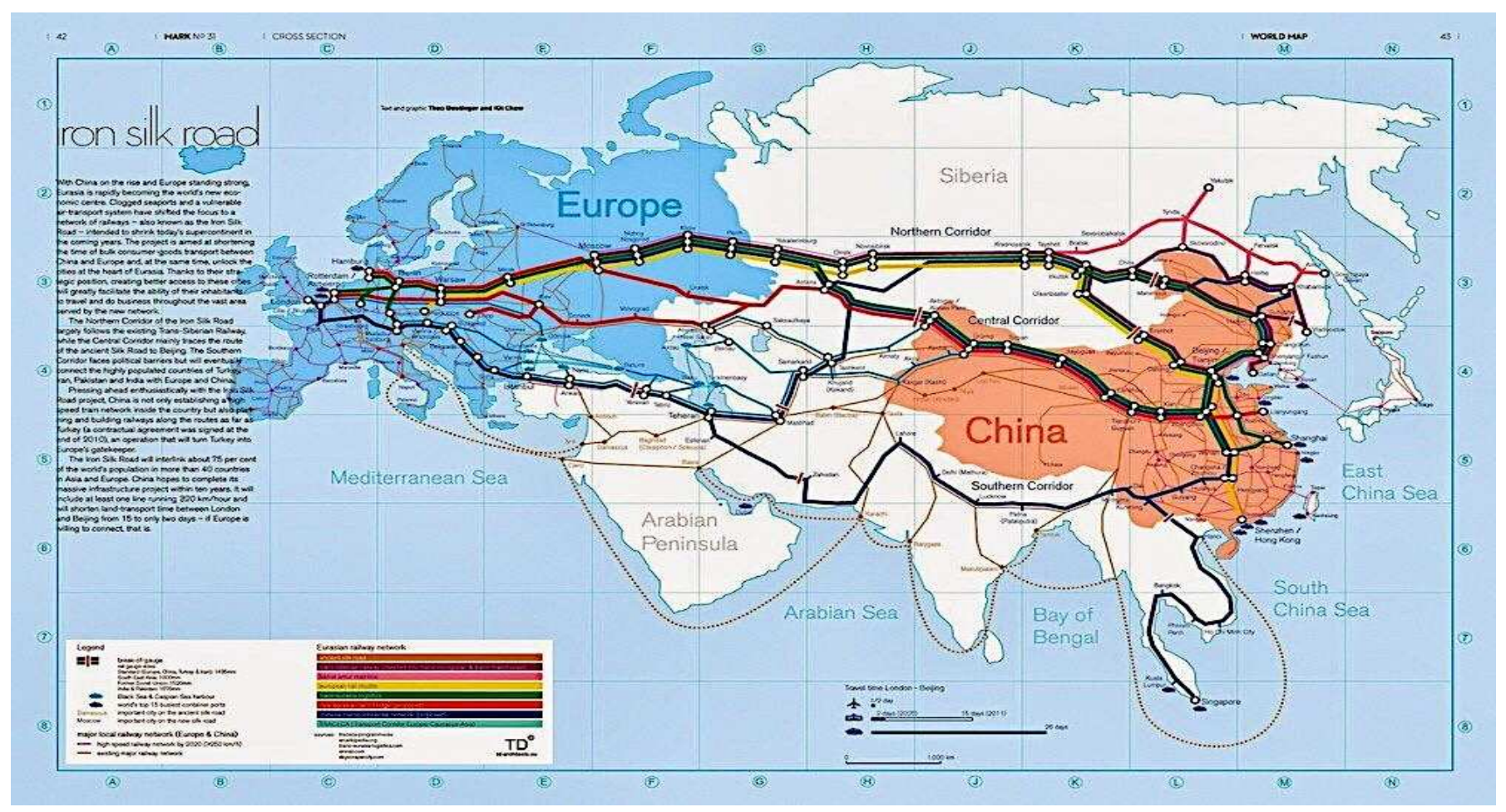

Fig. 3. A map of the main ways « The one belt and one road».

Among the main directions of China's strategic initiative, Railways occupy a special place, especially since China considers the economic belt of the Silk Road, primarily as the railway superhighway of Eurasia, which allows to establish and maintain reliable transport links with other parts of the
Silk Road zone to the borders of Europe through the territory of Kazakhstan.

Central Asia is the main objective of the Chinese concept of the Silk Road economic belt, which includes the modernization and construction of new railway lines, highways, pipelines and other infrastructure elements that contribute to the development of international and regional trade. The main cargo traffic along the Silk Road economic 
belt will be from East to West. Western and Central provinces of China will be connected with direct rail links with EU countries via Dostyk station (Kazakhstan) thanks to the new international transport corridors being created. Delivery of Chinese goods to Europe by rail is on average 2-3 times faster than by sea. It is a competitive advantage for the transportation of goods, especially critical to speed. On the figure 4 the transport prospects "land" corridor are presented [5].

Thus, we can state a high degree of demand in the China and Kazakhstan navigation equipment markets, which allows optimizing the logistics chain and tracking cargo $[6,7]$.

According to Rosstat, in Russia, the share of high-tech and science-intensive industries in GDP in 2016 reached $22.3 \%$ (which is $0.8 \%$ more than in 2015), while the main contribution to the growth of this indicator was made by the defense-industrial complex (Technologies are leaving ..., 2017; Rosstat). It is important to note that defense spending has increased from 2 trillion rubles in 2013 to 3.8 trillion rubles by 2016 (Ministry of Finance, RBC); the amount of the state defense order in 2015 amounted to 1.8 trillion rubles, which is $20 \%$ higher than in 2013 (State orders ..., 2016). As a result, there is a high probability that the growth in the share of high-tech industries in GDP, due to increased production in the defense-industrial complex, is unlikely to continue. One of the solutions to this problem is the creation of clusters with the use of small enterprises that will produce products based on the transfer of innovation of enterprises of the defense industry [8]. solving the problems associated with complex radio communication, confirming the uniqueness of the product offered to the creation of defense enterprises [6].

So we can state the need to create innovative navigation systems in Russia with the possibility of promoting this product on the world market. In Russia, China and Kazakhstan, there are practically no cheap, reliable and manufactured in the shortest possible time platforms for safe navigation of sea, land and air transport, capable of operating both in radio mode and with global satellite navigation systems of any manufacturer. Such systems were developed at the defense enterprises. In modern conditions of defense enterprises commercialization, innovation transfer to the consumer market becomes the most important. One of the directions of implementation of the above tasks is the creation of clusters, i.e. small enterprises using the transfer innovations of defense enterprises to create products in demand and adapted to the consumer market. One of such products is radio-air navigation systems [10].

A systematic approach to identification of threats to information security involves the implementation of an ongoing process that defines the scope of the threat definition process, identifies sources of threats and threats to information security, assesses the possibility of implementing information security threats and the extent of possible damage in the event of such implementation and reassessing threats to information security [2].

First of all, the cluster is spread all the variety of "typical"

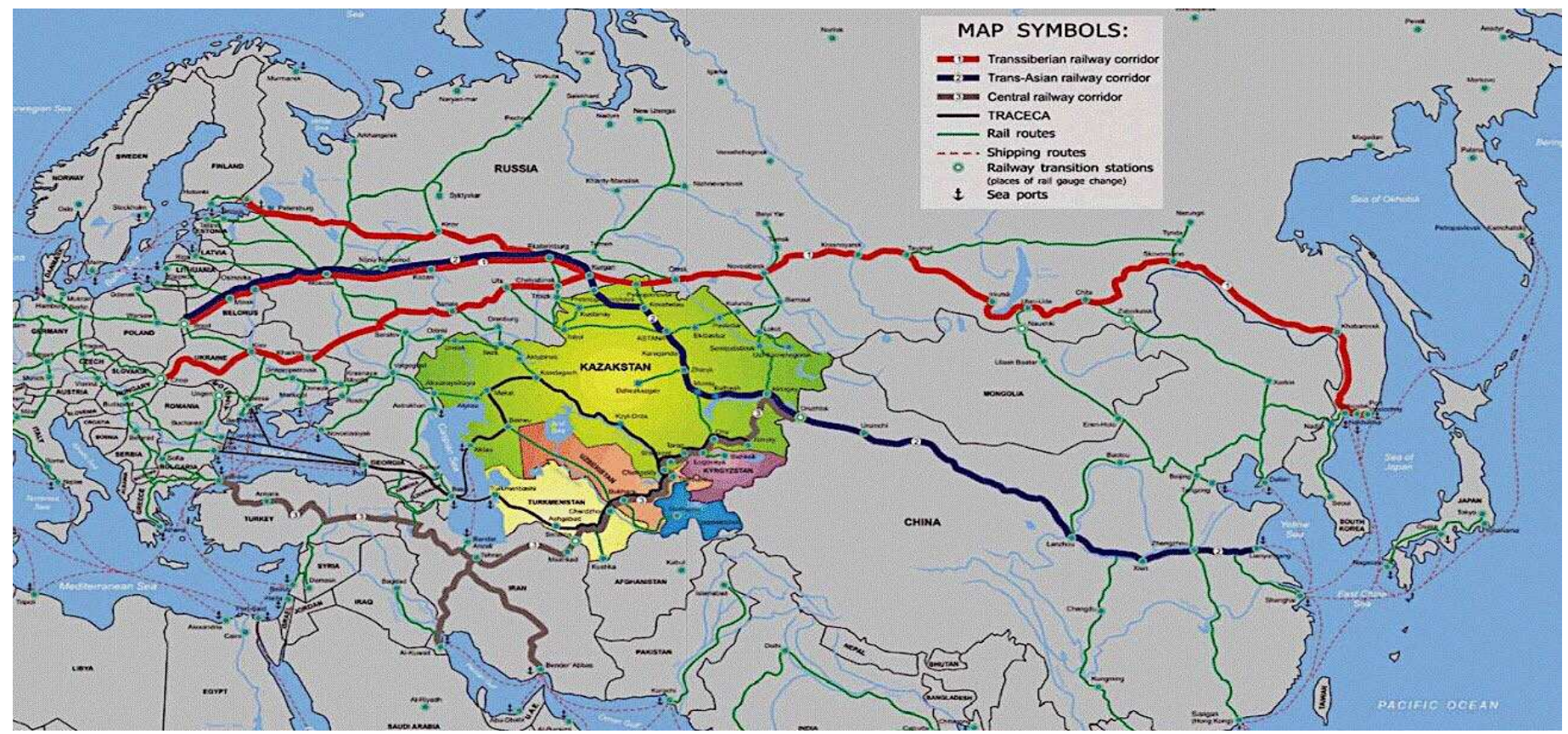

Fig. 4. Transport "land" corridor "Silk Road"

There are several major international competitors in the market including manufacturers. These enterprises belong to the military-industrial complex (hereinafter MIC) and large shipbuilding [9]. Small businesses, which are potential competitors, also implement their projects in the market of MariNet, but none of these competitors is not engaged in threats to information security, the set and variability of which is great. As already noted, it can be "idle", almost unmotivated hacker attacks, and purposeful deliberate negative influences on information systems [11].

As noted in this regard, the Deputy Prime Minister Russia D. I. Rogozin, "there have always been close, intensive ties between the military and civilian industries. They were based 
on the commonality of technology, the consumption of military products by civilian industries, for example, metallurgy and chemistry. Providing reciprocal flows of innovation and competences between defense and civil sectors will require a new attitude of the state and bureaucracy to the principles of information exchange, first of all, overcoming the tendency towards departmental and sectoral self-isolation. This is generally a "birthmark" of the defense industry. We very often, not always when it is needed, surround ourselves with a fence of confidentiality, and this often hurts, especially when transferring technology. This even harms the transfer of military technology between military corporations".

\section{COMPETITIVE ADVANTAGES OF THE CREATED PRODUCT, COMPARISON OF TECHNICAL AND ECONOMIC CHARACTERISTICS WITH WORLD ANALOGUES.}

In modern conditions, technical systems, including radioair navigation systems are becoming more focused on the end user [12 - 15]. The analysis was carried out to identify the basic requirements of end users to marine radio-air complexes. The results of the analysis are presented in table 2 .

TABLE II. CRITERIA OF THE ANALYSIS OF SIGNIFICANCE, WHICH DEFINE THE KEY REQUIREMENTS OF END USERS TO INNOVATIVE NAVIGATION SYSTEMS

\begin{tabular}{|c|c|c|}
\hline Criterion & $\begin{array}{c}\text { Test } \\
\text { significance }\end{array}$ & Comments \\
\hline $\begin{array}{l}\text { Positional } \\
\text { accuracy }\end{array}$ & High & $\begin{array}{c}\text { Accuracy is a critical } \\
\text { characteristic, because it is } \\
\text { directly related to the activity } \\
\text { performed in the field; the level } \\
\text { of accuracy must meet the } \\
\text { needs of the user }\end{array}$ \\
\hline $\begin{array}{l}\text { Security of } \\
\text { service }\end{array}$ & High & $\begin{array}{l}\text { Marine radio air systems } \\
\text { should provide a level of } \\
\text { reliability close to } 100 \%\end{array}$ \\
\hline $\begin{array}{l}\text { Client } \\
\text { service }\end{array}$ & High & $\begin{array}{l}\text { Client service is considered one } \\
\text { of the most important } \\
\text { characteristics for end users } \\
\text { who are willing to pay an } \\
\text { increased rate for a product that } \\
\text { guarantees support } 24 \text { hours a } \\
\text { day }\end{array}$ \\
\hline $\begin{array}{c}\text { Easy } \\
\text { handling }\end{array}$ & $\begin{array}{l}\text { Middle } \\
\text { (tends to } \\
\text { high) }\end{array}$ & $\begin{array}{l}\text { This characteristic is becoming } \\
\text { increasingly important for end- } \\
\text { users. The technology should } \\
\text { be easy to use even for } \\
\text { unprofessional workers who } \\
\text { are often hired for a short } \\
\text { period of time during the } \\
\text { seasonal peak of activity }\end{array}$ \\
\hline Cost & Middle & $\begin{array}{l}\text { The price of the device and the } \\
\text { service charge are always taken }\end{array}$ \\
\hline $\begin{array}{l}\text { Service } \\
\text { charge }\end{array}$ & Middle & $\begin{array}{l}\text { they are not always critical } \\
\text { criteria, as investments in } \\
\text { GNSS-based solutions pay off }\end{array}$ \\
\hline
\end{tabular}

\begin{tabular}{|c|c|c|}
\hline & & quickly \\
\hline $\begin{array}{l}\text { Convergence } \\
\text { time }\end{array}$ & Middle & \multirow{2}{*}{$\begin{array}{l}\text { These criteria are not } \\
\text { considered critical issues } \\
\text { because, on average, a good } \\
\text { service level is provided. }\end{array}$} \\
\hline $\begin{array}{l}\text { The time of } \\
\text { the first } \\
\text { location }\end{array}$ & Middle & \\
\hline $\begin{array}{c}\text { Device } \\
\text { interaction }\end{array}$ & Middle & $\begin{array}{l}\text { Large firms increasingly } \\
\text { require technology to be able to } \\
\text { communicate remotely with the } \\
\text { back office or other systems }\end{array}$ \\
\hline
\end{tabular}

As can be seen, such criteria as accuracy, reliability, client service have been the most important for the end users of innovative navigation systems.

\section{CONCLUSION}

In modern conditions of market globalization and the creation of international transport networks, the issues of accuracy and safety of cargo transportation are becoming the most relevant. Innovative navigation systems created on the basis of the defense enterprises innovation transfer can provide an opportunity of the solution of these questions.

As shown by the research, these devices can be used in all modes of transport and perform functions on long-distance transportation in sparsely populated areas. It is especially important for Siberia.

In the future, the segments of foreign markets, in particular Kazakhstan and China, are of particular interest. The unprecedented program "economic belt of the silk road" described above, based on the construction and resumption of many transport routes passing through China, Kazakhstan and Russia, presents many opportunities for the use of innovative navigation systems created on transfer of defense enterprises innovation.

\section{References}

[1] O.V. Bakulina, P. P. Topchiy, "Development of innovative potential of the region by the defense industry," Management Science, Moscow, 2017.

[2] S V. Uyanaev, "New "Silk Roads" of China: Principles and Parameters of the Official "Roadmap"," China in World and Regional Politics. History and modernity, 2015, vol. 20.

[3] T. N. Cheklina, "Prospects for cooperation of the countries of the Shanghai Cooperation Organization* within the framework of the project "Economic belt on the Great Silk Road"," Russian External Economic Bulletin, 2015, vol. 15, no. 2.

[4] O. V. Gosteva, A. A. Boyko, Transfer of innovations of high technology enterprises: problems, prospects, International Conference on Science, Agriculture, Engineering and Management Conference Proceedings, 2017, pp. 95-102.

[5] R.M. Nureyev, E.G. Busygin, "Economic sanctions as a factor in modernizing the defense industry of Russia," Journal of Institutional Studies, 2017, vol. 9, no. 3, pp. 97-118.

[6] S.V. Chemezov, N.A. Volobuev, Yu.N. Koptev, Kashirin AI Diversification, competencies, problems and tasks. New opportunities. Innovations, vol. 4, no. 222, pp. $3-27$. 
[7] E.N. Evdokimova, Innovations in strategic management of enterprises of the defense industry complex, Infrastructure sectors of the economy: problems and development prospects, 2016, no. 17, pp. 34-39.

[8] I.M. Golova, A.F. Sukhovey, "Innovation and technological development of industrial regions under social and economic insecurity," R-Economy, 2018, vol. 1, no. 1.

[9] A.M. Batkovskiy, V.V. Klochkov, E.G. Semenova, A.V. Fomina, and N. V. Cherner, "Management of Utilization and Development of the Production Capacity of the Military-Industrial Complex," Mediterranean Journal of Social Sciences, 2015, vol. 6.

[10] A. Dammann, R. Raulefs, S. Zhang, "On prospects of positioning in 5G, Communication Workshop (ICCW)," 2015 IEEE International Conference on, 2015, pp. 1207-1213.

[11] P.B. Lowry, C. Posey, R.B. Bennett, and T. L. Roberts, "Leveraging fairness and reactance theories to deter reactive computer abuse following enhanced organisational information security policies: An empirical study of the influence of counterfactual reasoning and organisational trust," Information Systems Journal, 2015, vol. 25, no. 3, pp. 193-273.

[12] G.E. Burnett, K. Lee The effect of vehicle navigation systems on the formation of cognitive maps, International conference of traffic and transport psychology, 2005.

[13] P.J. Winzer, R.J. Essiambre, "Advanced modulation formats for highcapacity optical transport networks," Journal of Lightwave Technology, 2006, vol. 24, no. 12, pp. 4711-4728.

[14] O.E. Atia, L.C. Monticone, L.Z. Ribeiro, J.C. Gonda, and D. Zeng, Preliminary investigation of data communications usage for unmanned aircraft systems, Integrated Communication, Navigation, and Surveillance Conference (ICNS), 2015.

[15] B.S. Ali, W.Y. Ochieng, W. Schuster, A. Majumdar, and T.K. Chiew, A safety assessment framework for the Automatic Dependent Surveillance Broadcast (ADS-B) system, Safety science, 2015, vol. pp. 78, 91-100. 